\title{
MANAJEMEN KEPALA SEKOLAH DALAM MEMBINA KARAKTER RELIGIUS PESERTA DIDIK DI SMP NEGERI 5 BATUSANGKAR, KECAMATAN LIMA KAUM, KABUPATEN TANAH DATAR, PROVINSI SUMATERA BARAT
}

\author{
Husnani \\ Guru SD Negeri 23 Sungai Tarab \\ Alamat: Piliang Lawas, Nagari Sungai Tarab, Kabupaten Tanah Datar, \\ e-mail: husnani22@gmail.com
}

\begin{abstract}
The religious character building program for students in State Secondary School 5 Batusangkar has shown maximum results. State Secondary School 5 Batusangkar is one of the schools that accommodate smart students. After doing the research, it turns out that they were not only smart on cognitive and psychomotor, but also on affective. This research was aimed at disclosing the management of principal in developing the religious character of students in State Secondary School 5 Batusangkar. This research was related to qualitative case study. The result revealed that the school principal has made planning, implementation, monitoring and evaluation of religious character building program for students. The activities were also supported by all parties. This research concluded that the principal of State Secondary School 5 Batusangkar had done a good management.
\end{abstract}

Keywords: Management, Principal, Religious Character, State Secondary School, Batusangkar

\section{PENDAHULUAN}

Tidak dapat dipungkiri bahwa pendidikan memiliki peranan yang sangat penting dalam pembangunan karena berorientasi pada peningkatan kualitas sumber daya manusia (SDM). Pendidikan merupakan suatu proses transformasi nilai-nilai budaya sebagai kegiatan pewarisan nilai-nilai dari satu generasi ke generasi selanjutnya. Tujuan pendidikan nasional menurut UU No. 20 Tahun 2003, Pasal 3 (tentang dasar, fungsi, dan tujuan dari pendidikan nasional), adalah untuk berkembangnya potensi peserta didik agar menjadi manusia yang beriman dan bertaqwa kepada Tuhan YME, berakhlak mulia, sehat, berilmu, cakap, kreatif, mandiri, dan menjadi warga negara yang demokratis serta bertanggung jawab (Tim Redaksi Fokus Media, 2006).

Tujuan pendidikan nasional ini haruslah menjadi muara dari setiap penyelenggaraan pendidikan yang ada di Negara Kesatuan 
Republik Indonesia, tanpa membedakan tingkat dan jenisnya, karena setiap bentuk penyelenggaraan pendidikan yang ada di NKRI adalah bahagian (sub sistem) dari pendidikan nasional. Dari tujuan pendidikan nasional yang tertuang dalam Undang-Undang Sisdiknas tersebut, terlihat ada beberapa aspek yang ingin diwujudkan pada diri peserta didik melalui proses pendidikan yang diikutinya, yakni aspek akal (menjadi manusia berilmu), aspek fisik (menjadi manusia yang sehat), dan kepribadian (menjadi manusia yang beriman dan bertaqwa kepada Tuhan Yang Maha Esa, berakhlak mulia, cakap, kreatif, mandiri, menjadi warga negara yang demokratis serta bertanggung jawab).

Jika kita lihat lebih dalam lagi dari ketiga aspek tersebut di atas, maka terlihat ada penekanan pada aspek kepribadian dan moralitas, yang di dalam dunia pendidikan Islam dikenal dengan nama akhlak, dan sekarang ini lebih dikenal dengan istilah karakter. Karakter menurut Kamus Besar Bahasa Indonesia adalah berarti sifat-sifat kejiwaan, akhlak atau budi pekerti yang membedakan seseorang dari yang lain (Tim Penyusun Kamus Pusat Pembinaan dan Pengembangan Bahasa, 1990). Sedangkan menurut Zuriah (2005) pengertian karakter sering disamakan dengan budi pekerti atau moralitas, dan moralitas mengandung pengertian adat istiadat atau sopan santun dan perilaku.

Berdasarkan pengertian di atas, dapat diketahui bahwa karakter merupakan bentuk dari perilaku yang dimiliki seseorang sebagai cerminan dari moralitas yang dimilikinya. Kita lihat lagi dari tujuan pendidikan nasional yang tertera dalam UndangUndang Sistem Pendidikan Nasional di atas, aspek karakter yang diharapkan dapat terbentuk melalui proses pendidikan adalah terciptanya manusia yang beriman dan bertaqwa kepada Tuhan Yang Maha Esa, berakhlak mulia, cakap, kreatif, mandiri, dan menjadi warga negara yang demokratis serta bertanggungjawab.

Diberikannya porsi yang lebih pada aspek pembentukkan karakter dalam tujuan pendidikan nasional Indonesia adalah merupakan sesuatu yang sangat pantas dan wajar. Ada beberapa alasan kenapa dikatakan pantas dan wajar, alasan yang pertama karena pembentukkan karakter atau kepribadian adalah merupakan sesuatu yang sesuai dengan pengertian dari pendidikan itu sendiri. Pendidikan menurut Kamus Besar Bahasa Indonesia adalah berasal dari kata "didik", "mendidik" yang dapat diartikan "memelihara dan memberikan latihan (ajaran, pimpinan) mengenai akhlak dan kecerdasan pikiran" (Tim Penyusun Kamus Pusat Pembinaan dan Pengembangan Bahasa, 1990). 
Sedangkan pengertian pendidikan menurut undang-undang sistem pendidikan nasional Nomor 20 Tahun 2003 yaitu usaha sadar dan terencana untuk mewujudkan suasana belajar dan proses pembelajaran agar peserta didik secara aktif mengembangkan potensi dirinya untuk memiliki kekuatan spiritual keagamaan, pengendalian diri, kepribadian, kecerdasan, akhlak mulia, serta keterampilan yang diperlukan dirinya, masyarakat, bangsa dan negara (Tim Redaksi Fokus Media, 2006). Dari pengertianpengertian di atas, jelas sekali terlihat adanya muatan pembentukkan karakter di dalamnya.

Alasan yang kedua adalah karena permasalahan pembentukkan karakter dewasa ini telah menjadi permasalahan yang sudah sangat serius yang melanda bangsa Indonesia. Sudah menjadi rahasia umum, kalau bangsa ini sedang dilanda krisis akhlak, krisis kepercayaan, terutama dari masyarakat terhadap pimpinannya. Korupsi, kolusi, nepotisme, pergaulan dan seks bebas, narkoba dan tawuran, serta berbagai perilaku buruk lainnya seakan telah menjadi warna dominan dari kebudayaan bangsa dewasa ini (Tilaar, 2004).

Keadaan inilah yang mendorong setiap elemen bangsa untuk berusaha memperbaiki keadaan yang ada karena dikhawatirkan rusaknya kepribadian bangsa akan menjadi penyebab menjauhnya rahmat Allah dari negeri ini, sebagaimana diingatkan Allah SWT dalam firman-Nya "jikalau sekiranya penduduk negeri-negeri beriman dan bertakwa, pastilah Kami akan melimpahkan kepada mereka berkah dari langit dan bumi, tetapi mereka mendustakan (ayatayat Kami) itu, Maka Kami siksa mereka disebabkan perbuatannya" (QS. Al-A'raaf: 96) (Departemen Agama, 2007).

Ayat di atas memberikan kabar gembira dan juga kabar pertakut (ancaman) dari Allah SWT. Bagi penduduk suatu negeri yang memiliki keimanan dan ketaqwaan diberikan kabar gembira dengan limpahan keberkatan dari langit dan bumi, sementara bagi negeri-negeri yang tidak beriman dan bertaqwa dan mendustakan ayat-ayat Allah, bagi mereka disediakan siksa. Menurut Yunus (2006) dalam tafsirnya, penduduk negeri yang beriman dan bertaqwa adalah mereka yang meninggalkan perbuatan haram serta melaksanakan aturan-aturan Islam dalam segala bidang kehidupannya. Hal demikian menurut Yunus (2006) tidak tampak di negeri Indonesia yang mayoritas penduduknya mengaku Islam, sebagai contoh setengah atau bahkan mayoritas saudagarnya melakukan perniagaan dengan jalan menipu.

Inilah di antaranya yang menjadikan rahmat dan berkah Allah menjadi jauh. 
Oleh sebab itu, agar negeri ini mendapat limpahan berkah dari Allah dan terhindar dari siksa-Nya, haruslah dilakukan perbaikan masyarakatnya dan dilahirkan kembali manusia Indonesia yang beriman dan bertaqwa, yang jabaran keduanya tercermin dalam karakter masyarakat yang baik, masyarakat yang berkualitas. Masyarakat seperti inilah yang ingin diwujudkan melalui penyelenggaraan pendidikan. Maka sangatlah tepat, dan bukan karena suatu kebetulan jika aspek pembentukkan karakter mendapatkan porsi yang lebih besar dalam tujuan pendidikan nasional.

Sekolah merupakan salah satu organisasi pendidikan yang dapat dikatakan sebagai wadah untuk mencapai tujuan pembangunan nasional. Keberhasilan suatu tujuan pendidikan di sebuah lembaga sekolah tergantung pada sumber daya manusia yang ada di sekolah tersebut seperti kepala sekolah, guru, peserta didik, pegawai, dan tenaga kependidikan lainnya. Selain itu juga harus didukung oleh sarana dan prasarana pendidikan yang memadai dalam kelancaran proses pendidikan.

Dalam proses untuk membentuk sumber daya manusia yang sesuai dengan tuntutan tujuan pembangunan nasional, maka dibutuhkan tenaga pendidik, tenaga kependidikan, dan peserta didik yang berkualitas tinggi. Menurut UU RI No.
20 tahun 2003, tentang sistem pendidikan nasional Bab XI pasal 39 menyatakan bahwa tenaga kependidikan bertugas melaksanakan administrasi, pengelolaan, pengembangan, pengawasan, dan pelayanan teknis untuk menunjang proses pendidikan pada satu satuan pendidikan. Selanjutnya pendidik merupakan tenaga profesional yang bertugas merencanakan dan melaksanakan proses pembelajaran, menilai hasil pembelajaran, melakukan bimbingan dan pelatihan, serta melakukan penelitian dan pengabdian kepada masyarakat, terutama bagi pendidik di perguruan tinggi.

Salah satu Sekolah Menengah Pertama (SMP), dari sejak berdirinya sampai sekarang memiliki program layanan keunggulan, yang berada di Kecamatan Lima Kaum, Kabupaten Tanah Datar, Propinsi Sumatera Barat yaitu Sekolah Menengah Pertama (SMP) Negeri 5 Batusangkar. Sekolah yang mulai beroperasi pada tahun ajaran 2004/2005 ini sampai sekarang masih terus eksis dan sangat memperhatikan sekali masalah pembinaan karakter religius peserta didik. Pembinaan karakter religius berarti melakukan pembinaan terhadap sikap peserta didik yang mencakup 3 (tiga) hal, yaitu 1) sikap dan perilaku yang patuh dalam melaksanakan ajaran agama yang dianutnya; 2) toleran terhadap pelaksanaan ibadah agama lain; dan 3) hidup rukun dengan pemeluk agama lain. 
Menurut Glock dan Stark (1966) dan Sahlan (2010) ada lima dimensi religius, di antaranya 1) dimensi keyakinan yang berisi pengharapan-pengharapan dimana orang religius berpegang teguh pada pandangan teologis tertentu dan mengakui keberadaan doktrin tersebut; 2) dimensi praktik agama yang mencakup perilaku pemujaan, ketaatan dan hal-hal yang dilakukan orang untuk menunjukkan komitmen terhadap agama yang dianutnya; 3) dimensi pengalaman. Dimensi ini berisikan dan memperhatikan fakta bahwa semua agama mengandung pengharapan-pengharapan tertentu; 4) dimensi pengetahuan agama yang mengacu kepada harapan bahwa orang-orang yang beragama paling tidak memiliki sejumlah minimal pengetahuan mengenai dasar-dasar keyakinan, ritus-ritus, kitab suci dan tradisi; 5) dimensi pengamalan atau konsekuensi. Dimensi ini mengacu pada identifikasi akibat-akibat keyakinan keagamaan, praktik, pengalaman, dan pengetahuan seseorang dari hari ke hari.

Pengembangan nilai-nilai karakter peserta didik ini termuat dalam Permendikbud No. 21 tahun 2015 tentang pembinaan karakter (penumbuhan budi pekerti). Untuk karakter religius, nilai-nilai mendasarnya adalah 1 ) internalisasi nilai-nilai moral dan spiritual, menghayati hubungan spiritual dengan sang pencipta dan diwujudkan dengan sikap moral keseharian untuk menghormati sesama makhluk hidup dan alam sekitar; 2) interaksi positif dengan sesama teman/ peserta didik, kepedulian terhadap kondisi fisik dan psikologis antar teman sebaya, adik dan kakak kelas; dan 3) interaksi positif dengan guru dan orang tua.

Dari grandtour yang telah peneliti lakukan pada hari Kamis, tanggal 12 Februari 2015, peneliti telah mendapatkan hasil bahwa SMP Negeri 5 Batusangkar tidak hanya fokus kepada peningkatan intelegensi peserta didik saja, tetapi juga memberikan perhatian yang sama kepada karakter religius peserta didiknya. Maka terdapat keseimbangan antara kognitif, afektif, dan psikomotor, sehingga lahirlah peserta didik yang cerdas dan bermoral.

Setelah melakukan penelitian awal ke Sekolah Menengah Pertama (SMP) Negeri 5 Batusangkar, maka peneliti telah melihat berbagai hal yang menjadi kelebihan/ keunggulan sekolah tersebut dibandingkan dengan sekolah yang lain. Berdasarkan potensi dan minat peserta didik sebagai pendukung utama program layanan keunggulan, maka juga dilaksanakan muatan lokal berbasis keunggulan global yakni English Conversation. Mata pelajaran ini dilaksanakan satu (1) jam pelajaran setiap minggu dengan orientasi pada kemampuan berbicara (speaking) (Studi Dokumentasi, 12 Februari 2015). 
Untuk muatan lokal berbasis keunggulan khusus, dilaksanakan pendidikan berbasis Surau Berisi yaitu pendidikan Tahfidz (hafalan ayat) Al-Qur'an serta peningkatan kualitas ibadah dengan dipandu oleh ustadz sekaligus Qori. Kelebihannya yang lain adalah pada kegiatan ekstrakurikuler yang merupakan kegiatan di luar mata pelajaran sebagai bagian integral dari kurikulum sekolah yang dilakukan melalui kegiatan pelayanan konseling dan kegiatankegiatan ekstrakurikuler. Kegiatan-kegiatan ekstrakurikuler yang ada adalah 1) Sains Club (pembinaan olimpiade); 2) English Club; 3) penelitian ilmiah pelajar (LPIP/ LPIR); 4) kepramukaan (wajib); 5) seni kreatif; 6) studi Islam intensif, forum annisa, forum ar-rijal; 7) keolahragaan (Sepak bola/futsal, Volley ball, Catur, Tenis meja, Badminton); 8) sanggar bahasa, mading, buletin sekolah (Studi Dokumentasi, 12 Februari 2015). Kegiatan pengembangan diri, tidak terprogram yang dilaksanakan yang dapat membina karakter religius peserta didik adalah sebagai berikut 1) rutin, yaitu kegiatan yang dilakukan terjadwal seperti upacara bendera, Budaya salam, Membaca Al-Qur'an beserta terjemahannya sebelum belajar, Menghafal ayat Al-Qur'an (tahfidz) sesudah belajar, Shalat Dhuha, Dhuhur, dan Ashar berjamaah, do'a dan dzikir sesudah shalat; 2) spontan, yaitu kegiatan tidak terjadwal dalam kejadian khusus seperti pembentukan perilaku memberi salam, membuang sampah pada tempatnya, dan budaya antri; 3) keteladanan, yaitu kegiatan dalam bentuk perilaku sehari-hari seperti berpakaian rapi, berbahasa Indonesia yang baik dan benar, rajin membaca, memuji kebaikan, dan tepat waktu (disiplin waktu) (Studi Dokumentasi, 12 Februari 2015).

Menurut Staf Kesiswaan SMP Negeri 5 Batusangkar, di dalam program kerja yang dibuat, ada beberapa kegiatan yang diprogramkan guna mewujudkan nilai-nilai karakter, yaitu 1) keimanan dan ketaqwaan; 2) kehidupan berbangsa dan bernegara; 3) pendidikan pendahuluan bela negara; 4) kepribadian dan budi pekerti luhur; 5) berorganisasi dan kepemimpinan; 6) keterampilan dan kewirausahaan; 7) persepsi dan daya kreasi seni; 8) kesegaran jasmani; 9) Masa Orientasi Siswa (MOS); dan 10) gerakan peduli siswa (Hasil Wawancara dengan Staf Kesiswaan SMP Negeri 5 Batusangkar, 06 Mei 2015).

Salah satu contoh kegiatan yang dilakukan guna untuk membina karakter peserta didik di SMP Negeri 5 Batusangkar adalah melalui Shalat Dzuhur berjamaah. Kegiatan sekolah yang satu ini tentunya sudah tak asing lagi bagi warga SMP Negeri 5 Batusangkar. Setiap pukul 12.00 WIB sekolah selalu memberi waktu istirahat 
selama 30 menit untuk bisa melaksanakan shalat Dzuhur berjamaah. Kegiatan keagamaan ini sangat bermanfaat dalam meningkatkan tali silaturahmi antara sesama warga SMP Negeri 5 Batusangkar, baik itu antara peserta didik dengan peserta didik ataupun peserta didik dengan guru. Selain itu, shalat berjamaah juga dapat membantu dalam membina karakter religius peserta didik (Hasil Observasi, 06 Mei 2015).

Peran sekolah bukan hanya sebatas mendidik peserta didiknya agar menjadi manusia yang pandai, tetapi sekolah juga mempunyai peran dalam membina karakter religius peserta didik agar mampu diterima dan membawa manfaat di lingkungan masyarakat. Sebagai salah satu sekolah negeri tentunya pandangan orang lain terhadap sekolah bermacam-macam. Sebagian besar masyarakat berpemikiran bahwa sekolah di negeri itu pengetahuan tentang agamanya kurang, padahal sekarang ini sudah banyak sekolah negeri yang mulai melaksanakan kegiatan keagamaan demi membina karakter peserta didiknya. Berdasarkan latar belakang tersebut maka manajemen kepala sekolah dalam membina karakter religius peserta didik di SMP Negeri 5 Batusangkar penting dikaji. Fokus dan sub fokus kajian dalam penelitian ini dapat dilihat pada gambar di bawah ini.

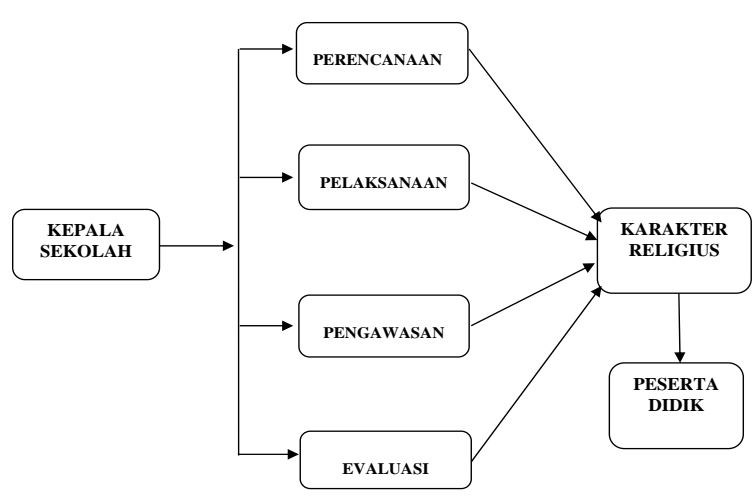

Gambar 1. Ruang Lingkup Masalah Penelitian

\section{METODE PENELITIAN}

Penelitian ini dilaksanakan di Sekolah Menengah Pertama (SMP) Negeri 5 Batusangkar, Kecamatan Lima Kaum, Kabupaten Tanah Datar, Propinsi Sumatera Barat. Peneliti telah mulai sejak tanggal 12 Februari 2015 sampai dengan tanggal 31 Juli 2015. Penelitian ini menggunakan pendekatan kualitatif. Kualitatif adalah metode penelitian yang digunakan untuk meneliti pada kondisi obyek yang alamiah, di mana peneliti adalah sebagai instrumen kunci, teknik pengumpulan data dilakukan secara triangulasi (gabungan), analisis data bersifat induktif/kualitatif, dan hasil penelitian kualitatif lebih menekankan makna dari pada generalisasi (Sugiyono, 2011). Dalam penelitian ini peneliti menggunakan metode observasi (pengamatan), wawancara, dan dokumen sebagai sumber data. Sedangkan informan data adalah kepala sekolah, guru, dan peserta didik. Kepala sekolah sebagai sumber data primer, sedangkan guru dan 
peserta didik sebagai sumber data sekunder. Sedangkan untuk teknik analisis data dapat dilihat pada gambar berikut.

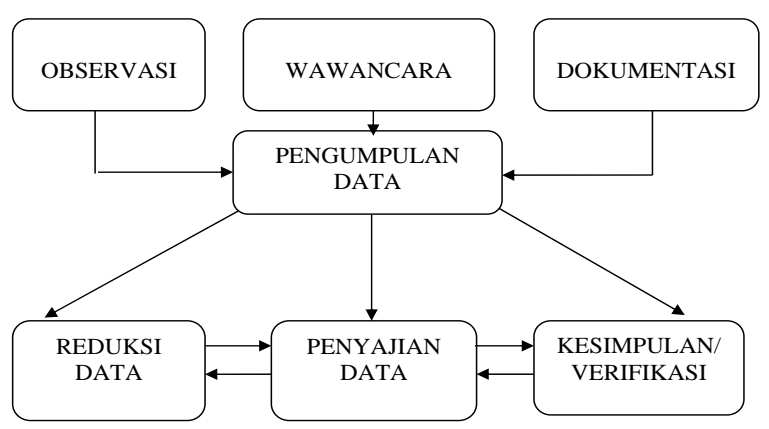

Gambar 2. Teknik Pengumpulan dan Analisis Data

Untuk menguji keabsahan data, peneliti menggunakan metode triangulasi dan perpanjangan pengamatan (tuntas dan jenuh). Peneliti melakukan cross check terhadap data yang telah diperoleh dari observasi, wawancara, dan studi dokumen.

\section{HASIL PENELITIAN DAN PEMBAHASAN}

\section{Perencanaan (Planning)}

Perencanaan adalah keseluruhan proses pemikiran dan penentuan secara matang menyangkut hal-hal yang akan dikerjakan di masa datang dalam rangka mencapai tujuan yang telah ditentukan sebelumnya. Membuat sebuah perencanaan yang matang untuk sebuah program pembinaan karakter religius peserta didik adalah suatu proses yang sangat penting dan harus dilalui, karena dengan adanya perencanaan yang matang maka kegiatanpun akan lebih terarah pada usaha pencapaian tujuan.
Dari pernyataan setiap responden yang telah peneliti wawancarai, mereka menyatakan bahwa setiap kegiatan yang akan dilaksanakan di SMP Negeri 5 Batusangkar ini harus membuat sebuah perencanaan dulu, mulai dari bentuk kegiatan, siapa saja yang terlibat dalam kegiatan, kapan kegiatan akan dilaksanakan, bagaimana cara melaksanakan kegiatan, dan hasil akhir apa yang diharapkan dari pelaksanaan kegiatan tersebut. Semua aspek ini diuraikan secara rinci dalam perencanaan, sehingga dapat terhindar dari kemungkinankemungkinan buruk yang akan mengganggu proses pelaksanaan kegiatan.

Dari hasil pengamatan dan studi dokumentasi, peneliti juga menemukan bukti telah dibuatnya sebuah perencanaan untuk program kegiatan pembinaan karakter religius peserta didik di SMP Negeri 5 Batusangkar yang dibuat dalam bentuk program kerja. Program kerja ini akan menjadi acuan untuk setiap kegiatan yang akan dilaksanakan.

\section{Pelaksanaan (Actuating)}

Fungsi pelaksanaan atau actuating merupakan bagian dari proses kelompok atau organisasi yang tidak dapat dipisahkan. Adapun istilah yang dapat dikelompokkan ke dalam fungsi ini adalah directing commanding, leading dan coordinating. Proses actuating adalah memberikan perintah, petunjuk, 
pedoman, dan nasehat serta keterampilan dalam berkomunikasi.

Menurut Kepala Sekolah dan Staf Kesiswaan, setiap kegiatan yang telah melalui proses perencanaan dan telah dituangkan dalam program kerja, kemudian dilaksanakan secara bersama oleh semua pihak yang terlibat. Kalau seandainya terjadi kendala dalam proses pelaksanaan kegiatan, baik itu dari peserta didik maupun guru, maka akan dibawa atau didiskusikan ulang di forum. Proses pelaksanaan program ini melibatkan semua pihak, dan membentuk koordinator yang memiliki tanggung jawab terhadap pelaksanaan kegiatan. Berdasarkan hasil observasi yang peneliti lakukan, semua warga sekolah memang melaksanakan setiap kegiatan bersama, termasuk juga kepala sekolah. Setiap kegiatan dilaksanakan dengan penuh kesadaran dan tanggung jawab. Meskipun tidak ada guru yang membimbing, peserta didik tetap melaksanakan kegiatan. Peserta didik tidak perlu disuruh-suruh lagi, mereka sudah tahu dengan jadwal yang telah ditetapkan.

Jadi tahap pelaksanaan ini harus ada dalam sebuah rangkaian program kegiatan, karena kalau tahap ini tidak ada maka perencanaan tidak ada gunanya. Setiap perencanaan yang telah dibuat harus dilaksanakan, agar dapat diketahui bagaimana hasilnya.

\section{Pengawasan (Controlling)}

Pengawasan atau controlling sering juga disebut dengan pengendalian adalah salah satu fungsi manajemen yang berupa mengadakan penilaian dan bila perlu sekaligus mengadakan koreksi sehingga apa yang sedang dilakukan oleh bawahan dapat diarahkan ke jalan yang benar, dengan maksud tercapai tujuan yang telah ditetapkan. Menurut hasil wawancara peneliti dengan wakil kepala sekolah, beliau mengatakan bahwa setiap pelaksanaan kegiatan harus dikontrol atau diawasi. Pengawasan dilakukan oleh wakil kepala, staf, dan kemudian dibuatkan laporan tertulisnya, yang akan disampaikan ke forum musyawarah/rapat. Dan secara tidak langsung, semua guru pun melakukan pengawasan terhadap setiap kegiatan yang dilakukan oleh peserta didik.

Pengawasan merupakan aktivitas yang mengusahakan agar pekerjaan dapat terlaksana sesuai dengan rencana atau tujuan yang telah ditetapkan. Pengawasan dapat diartikan sebagai upaya untuk mengamati secara sistematis dan berkesinambungan, merekam, memberi penjelasan, petunjuk, pembinaan dan meluruskan berbagai hal yang kurang tepat, serta memperbaiki kesalahan, dan merupakan kunci keberhasilan dalam keseluruhan proses manajemen. 
Dengan demikian dapat dipahami bahwa pengawasan merupakan salah satu cara kepala sekolah untuk mengetahui apakah usaha untuk pencapaian tujuan dari suatu kegiatan telah terlaksana dengan baik atau tidak. Kalau tidak baik, akan dicari tahu apa penyebabnya. Pengawasan juga sebagai pemantau efektifitas dari perencanaan, serta pengambilan perbaikan pada saat dibutuhkan.

\section{Evaluasi (Evaluating)}

Evaluasi adalah kegiatan yang dilakukan untuk mengetahui keadaan suatu obyek dengan menggunakan alat (instrumen) tertentu dan membandingkan hasilnya dengan standar tertentu untuk memperoleh kesimpulan. Evaluasi untuk pembinaan karakter dilakukan untuk mengukur apakah peserta didik sudah memiliki satu atau sekelompok karakter yang ditetapkan oleh sekolah dalam kurun waktu tertentu.

Hasil wawancara peneliti dengan kepala sekolah dan staf kesiswaan menyatakan bahwa setiap program yang telah direncanakan dan dilaksanakan harus di evaluasi. Bentuk evaluasi yang diberikan adalah evaluasi esidentil yaitu evaluasi yang langsung diberikan seketika/saat kegiatan telah selesai dilaksanakan. Ada juga evaluasi yang dilakukan secara keseluruhan, untuk semua kegiatan yang telah direncanakan dan dilaksanakan, dilakukan setiap akhir semester dan akhir tahun ajaran. Yang menjadi acuan evaluasi adalah program yang telah dibuat dan disepakati dalam kegiatan perencanaan.

Setelah melakukan observasi, peneliti mendapatkan hasil bahwa proses evaluasi kegiatan ini memang dilakukan oleh kepala sekolah, wakil/staf, serta oleh guru. Setelah melakukan evaluasi, maka akan diketahui hasilnya. Kemudian disampaikan kepada semua warga sekolah dalam sebuah rapat. Hasil dari evaluasi tersebut mempengaruhi untuk penentuan tindak lanjut. Dari hasil wawancara, observasi, dan studi dokumentasi yang telah peneliti lakukan di lokasi penelitian (SMP Negeri 5 Batusangkar), maka dapat dikatakan bahwa Kepala Sekolah telah melakukan perencanaan, pelaksanaan, pengawasan, dan evaluasi yang maksimal, sehingga memperoleh hasil sesuai dengan yang diharapkan. Dengan telah melalui proses pembinaan karakter religius, maka akan terbentuk peserta didik yang berkarakter.

\section{KESIMPULAN}

Berdasarkan hasil temuan penelitian yang telah peneliti jabarkan sebelumnya, maka dapat disimpulkan bahwa kepala sekolah telah melakukan berbagai usaha mulai dari proses perencanaan, pelaksanaan, pengawasan dan evaluasi terhadap kegiatan 
pembinaan karakter religius peserta didik SMP Negeri 5 Batusangkar, sehingga tercapainya hasil yang maksimal sesuai dengan yang diharapkan. Kegiatan ini juga telah didukung oleh semua pihak atau warga sekolah, dibuktikan dengan adanya komitmen bersama dalam perencanaan dan pelaksanaan kegiatan. Berdasarkan uraian di atas jelaslah bahwa kepala sekolah SMP Negeri 5 Batusangkar telah melakukan manajemen yang baik, dalam proses perencanaan sampai proses evaluasi. Hal ini dilakukan dalam proses membentuk peserta didik yang pintar dan berkarakter.

\section{KEPUSTAKAAN ACUAN}

Departemen Agama RI. (2007). Al-Qur'an dan Terjemahan. Jakarta: PT. Sygma Examedia Arkanlema.

Glock, C. \& Stark, R. (1966). Religion and Society In Tension. Chicago: University of California

Permendikbud No. 21 tahun 2015
Sahlan, Asmaun. (2010). Mewujudkan Budaya Religius di Sekolah. Malang: UIN MALIKI Press.

Sugiyono. (2011). Metode Penelitian Kuantitatif Kualitatif dan R\&D. Bandung: Alfabeta.

Tilaar, HAR. (2004). Paradigma Baru Pendidikan Nasional. Jakarta: Rineka Cipta.

Tim Penyusun Kamus Pusat Pembinaan dan Pengembangan Bahasa. (1990). Kamus Besar Bahasa Indonesia. Jakarta: Balai Pustaka.

Tim Redaksi Fokus Media. (2006). UndangUndang Republik Indonesia Nomor 20 Tahun 2003 Sisdiknas. Bandung: Fokus Media.

Undang-Undang RI No. 20 Tahun 2003 tentang Sistem Pendidikan Nasional

Yunus, Mahmud. (2006). Tafsir Al-Qur'an. Jakarta: Mahmud Yunus Wadzuryah.

Zariah, Nurul. (2005). Metodologi Penelitian Sosial dan Pendidikan. Jakarta: Bumi Aksara 